CLINICAL STUDY

\title{
Oncogenic mutations in the thyrotropin receptor of autonomously functioning thyroid nodules in the Japanese population
}

V Vanvooren, S Uchino ${ }^{1}$, L Duprez, M J Costa, J Vandekerckhove, J Parma, G Vassart, J E Dumont, J Van Sande and S Noguchi ${ }^{1}$

Institute of Interdisciplinary Research, University of Brussels, Campus Erasme, Route de Lennik 808, B-1070 Brussels, Belgium and ${ }^{1}$ Noguchi Thyroid Clinic and Hospital Foundation, 6-33 Noguchi Naka-machi, Beppu Oita, 874-0932, Japan

(Correspondence should be addressed to Vanessa Vanvooren; Email: vvvooren@ulb.ac.be)

\begin{abstract}
Objective: Constitutively activating mutations of the thyrotropin receptor (TSHR) have been found in the majority of autonomously functioning thyroid nodules (AFTNs) in European patients. The reported frequency of these mutations varies among reports but amounts to $50-80 \%$. To date, only one such mutation responsible for AFTNs has been identified in the Japanese population and the pathogenic role of such mutations in Japanese AFTNs has been questioned. In the present study, we evaluated the frequency of activating mutations in the TSHR and Gos in 10 Japanese AFTNs.

Design: Genomic DNA was extracted from fresh frozen tissue. The TSHR and the almost entire sequence of the gene coding for the $\alpha$ subunit of Gs have been amplified and sequenced.

Results: In sequence analysis, four mutations in the TSHR (T632A, I486M, M453T and L512R) were found. To complete our analysis, we searched mutations in the gene coding for the $\alpha$ subunit of Gs, in the samples negative for TSHR mutations. In one case a mutation (R201H) affecting GTPase activity was found.

Conclusions: If we focus on the solitary nodules, we obtain the same mutation proportion as in European patients $(70 \%)$. The absence of TSHR and G $\alpha$ s mutations in a significant proportion of autonomous adenomas in multinodular goiters suggests that other causes may also play a role in the genesis of these lesions.
\end{abstract}

European Journal of Endocrinology 147 287-291

\section{Introduction}

Under physiological circumstances, thyroid stimulating hormone (TSH) is the main factor that controls thyroid function and growth $(1-3)$. TSH acts by binding to its receptor which is a member of the large family of $\mathrm{G}$ protein-coupled receptors. In human thyroid, the TSH receptor activates adenylyl cyclase via a G $\alpha$ s protein and at higher concentrations phospholipase $\mathrm{C}$ via $\mathrm{Gq \alpha}$. The main second messenger of TSH action, in the human thyroid is cyclic AMP (cAMP) (2). Intracellular concentrations of cAMP control the maintenance of the differentiated phenotype of thyrocytes, the level of functional activity of the gland (trapping of iodide, secretion of thyroid hormones) and growth (3, 4). A chronic increase in this concentration is thus expected to cause toxic hyperplasia if all the thyrocytes of a gland are involved (4), or clonal expansion of the cell and an autonomous adenoma as a result of a somatic mutation. Clinically, autonomous functioning thyroid nodules (AFTNs) are well documented. They are well defined encapsulated benign tumors which grow, metabolize iodide and secrete thyroid hormones independently of TSH. They are diagnosed at scintigraphy by a high localized uptake of radioiodide or Tc-99m pertechnetate, surrounded by barely or nonvisible quiescent tissue. The low uptake of normal tissue results from low TSH serum levels, themselves a consequence of autonomous secretion of thyroid hormones by the nodule. AFTNs can be solitary or part of a multinodular goiter. In European patients, the main cause of this disease is mutations in the TSH receptor, increasing the constitutive activity of this receptor on adenylate cyclase $(5-8)$. The reported frequency of these mutations varies in different articles from $50-80 \%$ in Belgium and Germany $(6,9)$. These include studies in which only part of the TSH receptor (exon 10) has been sequenced. In Japan, a study including 
45 cases reported only one TSH receptor mutation, but no increase in the basal cAMP level could be demonstrated in cells transfected with this mutated receptor (10). Since then, one TSH receptor activating mutation has been found in a Japanese patient (11).

Any other player of the cAMP cascade, if activated, would lead to the same result as an activated TSH receptor. To date, two mutations of Gos have been identified; Q227L and R201H (in exons 8 and 9), which activate the protein, 'locking' it in its GTPbound signaling conformation leading to adenylyl cyclase activation in a receptor independent way (gsp mutations). gsp Mutations have been found in 3-6\% of AFTNs in Europe $(6,9)$. A Japanese study, Tanaka et al. (12), found only one case out of 38 studied. Although the discrepancies between the Japanese and the European studies may perhaps be explained by methodological differences (13), they raise the question whether the frequency of activating mutations in the $\mathrm{TSH}$ receptor and Gos in AFTNs is actually much lower in Japan than in Europe.

\section{Subjects and methods}

\section{Patients}

Ten adenomas and their juxtanodular tissue were obtained from Japanese patients. Some characteristics of the patients and their adenomas are summarized in Table 1. The diagnosis was established by scintigraphy. As shown in Table 1, four proven solitary adenomas were studied, three with total suppression of contralateral uptake, hyperthyroidism and decreased TSH levels and one with partial suppression of contralateral uptake, euthyroidism and decreased TSH levels. Six multinodular goiters were studied: three with hyperthyroidism and total suppression of contralateral uptake and TSH levels, two with euthyroidism, partial suppression of contralateral uptake and TSH levels and one with euthyroidism, normal TSH levels and partial suppression of contralateral uptake. The study was approved by the local ethical committee, and informed consent was obtained from all the participants before testing.

\section{Sequencing of the TSHR and G $\alpha$ s genes}

Fresh tissue, obtained by surgery in Japan, was frozen and sent to Brussels. Genomic DNA was extracted from adenomatous tissue and from juxtanodular quiescent tissue. Briefly, the samples were incubated with $10 \mathrm{mg} / \mathrm{ml}$ proteinase $\mathrm{K}$ in $50 \mathrm{mM}$ Tris $-\mathrm{HCl} \mathrm{pH} 8.0$, $100 \mathrm{mM}$ EDTA, $100 \mathrm{mM} \mathrm{NaCl}$ and $1 \%$ SDS at $56^{\circ} \mathrm{C}$ overnight, then phenol extracted and ethanol precipitated. Genomic DNA was finally resuspended in $500 \mu \mathrm{l}$ TE pH 7.5 (10 mM Tris-HCl, 1 mM EDTA). All coding portions of the TSH receptor gene were sequenced using a total of 14 PCR amplified fragments. Except for exon 1, the entire G $\alpha$ s gene was amplified using nine couples of primers. Table 2 summarizes the pairs of primers chosen to amplify the TSHR and Gos. Each PCR was performed in a final volume of $20 \mu \mathrm{l}$ containing $200 \mathrm{ng}$ DNA, $0.5 \mu \mathrm{l}$ Taq DNA polymerase (BRL), $3 \mathrm{pmol}$ of each primer, $10 \mathrm{mM}$ Tris-HCl pH 8.3, $50 \mathrm{mM} \mathrm{KCl}, \quad 1.5 \mathrm{mM} \mathrm{MgCl}_{2}, 0.01 \%$ gelatin and

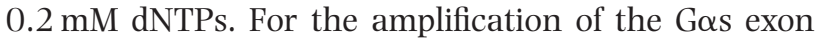
12, we used the Ampli Taq Gold (Roche). All the reactions were started by an initial denaturation at $93^{\circ} \mathrm{C}$ for

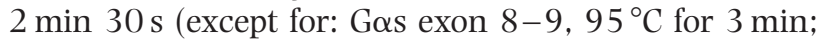

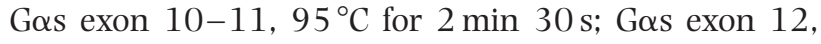
$95^{\circ} \mathrm{C}$ for $12 \mathrm{~min}$ ) followed by 30 cycles (for the $\mathrm{G} \alpha \mathrm{s}$ exon 6: 35 cycles). Annealing temperature was $54^{\circ} \mathrm{C}$ for TSHR $1,4,5,7 ; 48^{\circ} \mathrm{C}$ for TSHR 2, 10 residues 635-stop; $52^{\circ} \mathrm{C}$ for TSHR 3, 6, 8, 10 residues 295344,10 residues $430-537$, G $\alpha$ s exon $7 ; 61^{\circ} \mathrm{C}$ for TSHR 9; $50{ }^{\circ} \mathrm{C}$ for TSHR 10 residues 322-449, 10 residues 526-646, Gas exon 3, 4-5, 10-11, 12, 13; $58{ }^{\circ} \mathrm{C}$ for $\mathrm{G} \alpha$ s Exon 2,6 and $59{ }^{\circ} \mathrm{C}$ for $\mathrm{G} \alpha$ s exon 8-9.

PCR products were sequenced on both strands using the DNA Sequencing Kit (PE Applied Biosystems).

Table 1 Summary of characteristics of the 10 AFTNs investigated in this study.

\begin{tabular}{|c|c|c|c|c|c|c|c|c|}
\hline Patient & Sex & $\begin{array}{c}\text { Nodule } \\
\text { (By echography) }\end{array}$ & $\begin{array}{l}\text { Suppression of } \\
\text { contralateral } \\
\text { (By scintigraphy) }\end{array}$ & $\begin{array}{c}\text { FT3 } \\
(\mathrm{pg} / \mathrm{ml})\end{array}$ & $\begin{array}{c}\text { FT4 } \\
\text { (ng/dl) }\end{array}$ & $\begin{array}{c}\text { TSH level } \\
\mu U / m l\end{array}$ & $\begin{array}{c}\text { TSHR } \\
\text { mutation }\end{array}$ & $\begin{array}{c}\text { Gos } \\
\text { mutation }\end{array}$ \\
\hline 2 & $\mathrm{~F}$ & Multiple & + & 5 & 2.2 & 0.0 & T632A & ND \\
\hline 3 & $\mathrm{~F}$ & Multiple & + & 5.8 & 1.6 & 0.0 & - & - \\
\hline 4 & M & Multiple & $+1-$ & 3.4 & 1.1 & 0.2 & I486M & ND \\
\hline 5 & $\mathrm{~F}$ & Multiple & + & 3.3 & 1.7 & 0.1 & - & - \\
\hline 6 & $\mathrm{~F}$ & Multiple & $+1-$ & 2.9 & 1.2 & 0.4 & - & - \\
\hline 7 & $\mathrm{~F}$ & Solitary & + & 5.8 & 2.2 & 0.0 & - & $\mathrm{R} 201 \mathrm{H}$ \\
\hline 8 & $\mathrm{~F}$ & Solitary & + & 7.0 & 3.7 & 0.0 & L512R & ND \\
\hline 9 & M & Solitary & $+1-$ & 3.8 & 1.1 & 0.2 & - & - \\
\hline 10 & $M$ & Solitary & + & 4.9 & 1.5 & 0.1 & M453T & ND \\
\hline Normal values & & & & $2.2-4.3$ & $0.8-1.5$ & $0.7-4.3$ & & \\
\hline
\end{tabular}

ND, not determined. Scintigraphy: + , total suppression of uptake in the contralateral lobe; $+/-$, partial suppression of uptake in the contralateral lobe. For TSH 0.0 means $<0.1 \mu \mathrm{U} / \mathrm{ml}$. 
Table 2 Summary of the primers used for the PCR amplification of the TSHR and G $\alpha$ s.

\begin{tabular}{|c|c|c|}
\hline Exon & Forward primer & Reverse primer \\
\hline TSHR 1 & $5^{\prime}$ M13D GAGGATGGAGAAATAGCCCCGAG $3^{\prime 1}$ & $5^{\prime}$ M13R CACTACTTCGGGCTGTTATTGAG $3^{\prime 1}$ \\
\hline TSHR 2 & $5^{\prime}$ M13D TAAGGTGAATTATTAGAAAAGC $3^{\prime 1}$ & $5^{\prime}$ M13R CTTGATAGAACACGTTTAGAGAA $3^{\prime 1}$ \\
\hline TSHR 4 & $5^{\prime}$ SP6 ACCCTGTGGCGTAAATGCATAT $3^{\prime 1}$ & $5^{\prime}$ M13R CCCGACCCAGGCTATACACCATT $3^{\prime 1}$ \\
\hline TSHR 5 & $5^{\prime}$ M13D AGTTTGACTACAGGTTGTCTTC $3^{\prime 1}$ & $5^{\prime}$ M13R GCTTTACTTATCTTCAACCTACC $3^{\prime 1}$ \\
\hline TSHR 6 & $5^{\prime}$ M13D TATTGTGTCCTGTTATTTAAGTGCATA $3^{\prime 1}$ & $5^{\prime}$ M13R GTACTCTATAGAGTATATATGATAAGG $3^{\prime 1}$ \\
\hline TSHR 7 & $5^{\prime}$ M13D TGGGATACATATGTGGGACCTG $3^{\prime 1}$ & $5^{\prime}$ M13R TGTTGGGTCACACTAACTCTGG $3^{\prime 1}$ \\
\hline TSHR 8 & 5' M13D TGGTCACATTTTATTCTGATATTTG $3^{\prime}$ & $5^{\prime}$ M13R ATATTCTTTTGTATGTCTTACTC $3^{\prime}$ \\
\hline TSHR 9 & $5^{\prime}$ M13D TCATCTCCCAATTAACCTCAGG $3^{\prime 1}$ & $5^{\prime}$ M13R GCTTCCAATTTCСTCTCCAC $3^{\prime 1}$ \\
\hline TSHR 10 residues $295-344$ & $5^{\prime}$ M13D TGGCACTGACTCTTTTCTGT $3^{\prime 1}$ & $5^{\prime}$ M13R TGAGCGTTGTTATGAGTATCC $3^{\prime}$ \\
\hline TSHR 10 residues $322-449$ & 5' M13D TGTGAATGCCTTGAATAGCC $3^{\prime}$ & 5' M13R CAGGTTGCACATGAGAAAGC 3' \\
\hline TSHR 10 residues $430-537$ & $5^{\prime}$ M13D TTCGTTAGTCTGCTGGCTC $3^{\prime}$ & $5^{\prime}$ M13R CAACCATGATGGCACATG $3^{\prime}$ \\
\hline TSHR 10 residues $526-646$ & $5^{\prime}$ M13D CTGGTATGCCATCACCTTC $3^{\prime}$ & $5^{\prime}$ M13R TGAGAGGCTTGTTCAGAATT $3^{\prime}$ \\
\hline TSHR 10 residues 635stop & $5^{\prime}$ M13D TGTTGATCTTCACCGACTTC $3^{\prime}$ & $5^{\prime}$ M13R TAAGTTCCCCTACCATTGTG $3^{\prime}$ \\
\hline Gos 2 & 5' M13D GACCTCCСТGCCCAAAGT 3' & $5^{\prime}$ M13R CCCCAAAGCCCACCTATA $3^{\prime}$ \\
\hline $\mathrm{G} \alpha \mathrm{s} 3$ & $5^{\prime}$ M13D CTGATGGTTGAGGAATGTAG $3^{\prime}$ & $5^{\prime}$ M13R CGGTCTGCCTCAGTTTC 3' \\
\hline $\mathrm{G} \alpha \mathrm{s} 6$ & $5^{\prime}$ M13D TCAGGGTTTGAATGACAGTG 3' & $5^{\prime}$ M13R TTATGTGCTGATGGGTTGG $3^{\prime}$ \\
\hline $\mathrm{G} \alpha \mathrm{s} 7$ & $5^{\prime} \quad$ TGCCATTGACTTAGTGCTGC $3^{\prime}$ & $5^{\prime} \quad$ CAGAAGTCAGGACACGGCAG $3^{\prime}$ \\
\hline $\mathrm{G} \alpha \mathrm{s} 8-9$ & $5^{\prime}$ M13D CTCCCCACCAGAGGACTCTGAGCC $3^{\prime}$ & 5' M13R AGAGCGTGAGCAGCGACCCTGATC 3' \\
\hline Gos 10-11 & $5^{\prime}$ M13D GGCTGTTCGTAAAGAACG $3^{\prime}$ & $5^{\prime}$ M13R GAACCACCGCAATGAACAGC $3^{\prime}$ \\
\hline $\mathrm{G} \alpha \mathrm{s} 12$ & $5^{\prime}$ M13D CTAGCACCCCAGCTCTGCTTG $3^{\prime}$ & $5^{\prime}$ M13R CATGGAACTGGGTAGCTGAAC $3^{\prime}$ \\
\hline $\mathrm{G} \alpha \mathrm{s} 13$ & 5' M13D CATCAGGGATAGGGTGGTTC 3' & 5' M13R CTTGTACAATTACGTTTCAC $3^{\prime}$ \\
\hline
\end{tabular}

${ }^{1}$ Primers defined by de Roux et al. (14); M13D, M13R and SP6 correspond to universal sequencing primers (ABI).

Samples were loaded on an Applied Biosystems 373 Stretch Sequencing Instrument and analyzed using the Factura and Sequence Navigator software (ABI).

\section{Results}

By sequencing the entire TSHR gene in 10 AFTNs from Japanese patients, four mutations were identified (Table 1). The only mutation L512A described in the Japanese population by Kosugi (11) was among the four mutations found. Three mutations detected (I486M, M453T and L512R) have already been reported in the European population and all enhance the constitutive activity of the receptor versus adenylate cyclase when expressed in eukaryotic cells $(6,9,14$, 15). The fourth T632A has been found in AFTN and cancer but its activating effect has not yet been demonstrated $(9,16)$, although the similar mutation T632I has been shown to confer constitutive activity to the receptor. All mutations were heterozygous and detectable only in the adenomatous tissue, not in the surrounding tissue. The samples which were negative for TSHR mutation were screened for G $\alpha$ s mutations. Although in general only exons 8 and 9 are investigated for mutations, we have completely sequenced the exons 2 to 13 of the G $\alpha$ s protein (gsp gene). The first exon could not be amplified by PCR because of the high GC content. One heterozygous Gas mutation in position 201, leading to an exchange of arginine to histidine was found in an adenoma. This activating gsp mutation has previously been identified in thyroid tumors $(6,9,17)$.

\section{Discussion}

In the present study, we examined the incidence of TSHR and gsp mutations in a series of 10 autonomous thyroid adenomas from Japan. In a previous study, Takeshita et al. (10) examined 45 AFTNs in Japanese patients. They had found a TSHR gene alteration (deletion of three adenines which resulted in Asp 619 deletion) in only one case. This mutant did not show constitutive activation in transfection experiments. They concluded that there was no activating mutation of the TSHR in AFTNs in the Japanese population. However, the possibility that the AFTNs examined had TSHR mutations cannot be excluded because only a 167 base pair region was analyzed. Kosugi et al. who had identified a mutation responsible for AFTNs in the Japanese population sequenced the entire exon 10 of the receptor. However amino acid substitutions conferring constitutive activity of the TSHR have also been found elsewhere in the extracellular amino-terminal domain (18). We therefore sequenced the entire TSHR gene and identified four activating TSHR mutations among the 10 AFTNs from Japanese patients. We also searched for mutations in the gene coding for the $\alpha$ subunit of Gs. We analyzed not only the two hot spots classically described but almost the entire sequence from exon 2 to 13 of the protein Gos. One mutation at position 201, corresponding to one of the known hot spots affecting the GTPase activity, was discovered in one of the AFTN negative for TSHR activating mutations. The sequencing of the other coding portions of the G $\alpha$ s has not revealed any other mutation. Thus the incidence of 
oncogenic mutations of proteins of the cAMP cascade in Japanese AFTN is not rare. Indeed, the frequency of such mutations in Europe is $50-80 \%$. The discrepancy of the prevalence of TSHR mutations among AFTNs found in different populations was suggested to be associated with the different ethnic origins of the patients (10). It may in fact mainly be related to the completeness of the sequencing. It may also be related to the correspondence of the diagnosis in the different countries. It is also interesting that among the four solitary adenomas investigated, three demonstrated activating mutations of the TSH receptor or Gos, i.e. the same proportion as in Europe. These three adenomas are those in which all the criteria for the diagnosis were fulfilled: hyperthyroidism, low TSH levels and suppression of the uptake in the contralateral lobe. For the adenoma in which no mutation was found, the patient was not hyperthyroid, and both the contralateral uptake and the TSH levels were only partially suppressed. Only two activating mutations have been found in six hot nodules of multinodular goiters. One among the three patients with hyperthyroidism and suppression of contralateral uptake and TSH levels; one among the two who were not hyperthyroid and had only partial suppression of uptake and TSH levels; none in patient 1 , who was euthyroid, had normal TSH levels and only partial suppression of contralateral uptake. The diagnosis of this latter adenoma is therefore doubtful. The Belgian and Italian statistics apply to solitary adenomas although mutations have been found in different nodules of the same toxic multinodular goiter, but less frequently (19-22). It should be noted that whereas single nodules are most often monoclonal, nodules of multinodular goiters are often polyclonal $(23,24)$. The absence of TSHR and Gos mutations in a significant proportion of autonomous adenomas suggests that other mutations may be found in the proteins of the cAMP cascade downstream of $\mathrm{G} \alpha \mathrm{s}$ or even in proteins of other cascades provided that the mutation leads to proliferation with conservation of differentiation (for example, constitutive activation of the IGF1 receptor, by IGF1, in transgenic mice leads to thyroid autonomy) (25).

The real difference between Japan and Europe is the low prevalence of autonomous adenomas in Japan, low prevalence has also been shown in the United States (26). This has been related to the high level of dietary iodide which has been shown in Denmark (27) and in Switzerland (28) to be inversely related to the incidence of thyroid autonomous adenomas.

\section{Acknowledgements}

$\mathrm{V}$ Vanvooren is a fellow of the Fonds pour la formation à la Recherche dans l'Industrie et dans l'Agriculture. This work was supported by the Ministère de la Politique Scientifique (PAI), the Fonds National de la
Recherche Scientifique and Fonds de la Recherche Scientifique Médicale, Fonds Cancérologiques de la CGER, Association contre le Cancer, Association Sportive contre le Cancer, and Télévie.

\section{References}

1 Dumont JE, Vassart G \& Refetoff S. Thyroid disorders. In The Metabolic and Molecular Bases of Inherited Diseases, pp 1843-1879. Ed. CR Scriver. New York: McGraw-Hill, 1989.

2 Dumont JE, Lamy F, Roger P \& Maenhaut C. Physiological and pathological regulation of thyroid cell proliferation and differentiation by thyrotropin and other factors. Physiological Reviews $199272667-697$.

3 Vassart G \& Dumont JE. The thyrotropin receptor and the regulation of thyrocyte function and growth. Endocrine Reviews $199213596-611$.

4 Dumont JE, Jauniaux JC \& Roger PP. The cyclic AMP-mediated stimulation of cell proliferation. Trends in Biochemical Sciences $19891467-71$.

5 Parma J, Duprez L, Van Sande J, Cochaux P, Gervy C, Mockel J et al. Somatic mutations in the thyrotropin receptor gene cause hyperfunctioning thyroid adenomas. Nature $1993 \mathbf{3 6 5} 649-651$.

6 Parma J, Duprez L, Van Sande J. Hermans J, Rocmans P, Van Vliet $\mathrm{G}$ et al. Diversity and prevalence of somatic mutations in the thyrotropin receptor and Gs alpha genes as a cause of toxic thyroid adenomas. Journal of Clinical Endocrinology and Metabolism 1997 82 2695-2701.

7 Porcellini A, Ciullo I, Laviola L, Amabile G, Fenzi G \& Avvedimento VE. Novel mutations of thyrotropin receptor gene in thyroid hyperfunctioning adenomas. Rapid identification by fine needle aspiration biopsy. Journal of Clinical Endocrinology and Metabolism $199479657-661$.

8 Russo D, Arturi F, Suarez HG, Schlumberger M, Du Villard JA, Crocetti U et al. Thyrotropin receptor gene alterations in thyroid hyperfunctioning adenomas. Journal of Clinical Endocrinology and Metabolism 199681 1548-1551.

9 Trulzsch B, Krohn K, Wonerow P, Chey S, Holzapfel HP, Ackermann F et al. Detection of thyroid-stimulating hormone receptor and Gsalpha mutations in 75 toxic thyroid nodules by denaturing gradient gel electrophoresis. Journal of Molecular Medicine 2001 78 684-691.

10 Takeshita A, Nagayama Y, Yokoyama N, Ishikawa N, Ito K, Yamashita T et al. Rarity of oncogenic mutations in the thyrotropin receptor of autonomously functioning thyroid nodules in Japan. Journal of Clinical Endocrinology and Metabolism $1995 \mathbf{8 0}$ 2607-2611.

11 Kosugi S, Hai N, Okamoto H, Sugawa H \& Mori T. A novel activating mutation in the thyrotropin receptor gene in an autonomously functioning thyroid nodule developed by a Japanese patient. European Journal of Endocrinology 2000143 471-477.

12 Tanaka K, Nagayama Y, Takeshita A, Namba H, Yamashita S, Niwa $\mathrm{M}$ et al. Low incidence of the stimulatory G protein alphasubunit mutations in autonomously functioning thyroid adenomas in Japan. Thyroid 19966 195-199.

13 Tonacchera M, Cetani F, Parma J, Van Sande J, Vassart G \& Dumont J. Oncogenic mutations in thyroid adenoma: methodological criteria. European Journal of Endocrinology 1996135 444-446.

14 de Roux N, Polak M, Couet J, Leger J, Czernichow P, Milgrom E et al. A neomutation of the thyroid-stimulating hormone receptor in a severe neonatal hyperthyroidism. Journal of Clinical Endocrinology and Metabolism $1996812023-2026$.

15 Parma J, Van Sande J, Swillens S, Tonacchera M, Dumont J \& Vassart G. Somatic mutations causing constitutive activity of the thyrotropin receptor are the major cause of hyperfunctioning thyroid adenomas: identification of additional mutations activating both the cyclic adenosine $3^{\prime}, 5^{\prime}$-monophosphate and inositol 
phosphate-Ca ${ }^{2+}$ cascades. Molecular Endocrinology $1995 \quad 9$ $725-733$.

16 Spambalg D, Sharifi N, Elisei R, Gross JL, Medeiros-Neto G \& Fagin JA. Structural studies of the thyrotropin receptor and Gs alpha in human thyroid cancers: low prevalence of mutations predicts infrequent involvement in malignant transformation. Journal of Clinical Endocrinology and Metabolism $1996813898-3901$.

17 Lyons J, Landis CA, Harsh G, Vallar L, Grunewald K, Feichtinger H et al. Two G protein oncogenes in human endocrine tumors. Science $1990249655-659$.

18 Duprez L, Parma J, Costagliola S, Hermans J, Van Sande J, Dumont JE et al. Constitutive activation of the TSH receptor by spontaneous mutations affecting the N-terminal extracellular domain. FEBS Letters $1997 \mathbf{4 0 9} 469-474$.

19 Duprez L, Hermans J. Van Sande J. Dumont JE, Vassart G \& Parma J. Two autonomous nodules of a patient with multinodular goiter harbor different activating mutations of the thyrotropin receptor gene. Journal of Clinical Endocrinology and Metabolism 199782 306-308.

20 Tonacchera M, Agretti P, Chiovato L, Rosellini V, Ceccarini G, Perri A et al. Activating thyrotropin receptor mutations are present in nonadenomatous hyperfunctioning nodules of toxic or autonomous multinodular goiter. Journal of Clinical Endocrinology and Metabolism 200085 2270-2274.

21 Gabriel EM, Bergert ER, Grant CS, van Heerden JA, Thompson GB \& Morris JC. Germline polymorphism of codon 727 of human thyroid-stimulating hormone receptor is associated with toxic multinodular goiter. Journal of Clinical Endocrinology and Metabolism $1999843328-3335$.

22 Holzapfel HP, Fuhrer D, Wonerow P, Weinland G, Scherbaum WA \& Paschke R. Identification of constitutively activating somatic thyrotropin receptor mutations in a subset of toxic multinodular goiters. Journal of Clinical Endocrinology and Metabolism 199782 4229-4233.

23 Krohn K, Fuhrer D, Holzapfel HP \& Paschke R. Clonal origin of toxic thyroid nodules with constitutively activating thyrotropin receptor mutations. Journal of Clinical Endocrinology and Metabolism 199883 130-134.

24 Derwahl M. Molecular aspects of the pathogenesis of nodular goiters, thyroid nodules and adenomas. Experimental and Clinical Endocrinology Diabetes 1996104 (Suppl 4) 32-35.

25 Clement S, Refetoff S \& Robaye B. Low TSH requirement and goiter in transgenic mice overexpressing IGF-I and IGF-I receptor in the thyroid gland. Endocrinology 2001142 5131-5139.

26 Laurberg P, Nohr SB, Pedersen KM, Hreidarsson AB, Andersen S, Bulow Pedersen I et al. Thyroid disorders in mild iodine deficiency. Thyroid 200010 951-963.

27 Laurberg P, Pedersen KM, Vestergaard H \& Sigurdsson G. High incidence of multinodular toxic goitre in the elderly population in a low iodine intake area vs. high incidence of Graves' disease in the young in a high iodine intake area: comparative surveys of thyrotoxicosis epidemiology in East-Jutland Denmark and Iceland. Journal of Internal Medicine 1991229 415-420.

28 Als C \& Rosler H. Toxic adenomas of the thyroid gland becoming less frequent in Berne. Schweizerische Medizinische Wochenschrift $19951251495-1499$.

Received 13 March 2002

Accepted 29 May 2002 